\title{
Influence of Hydrogen Flow Rates Annealing on the Structural, Optical and Electrical Properties of Sol-Gel Synthesized Fe doped $\mathrm{In}_{2} \mathrm{O}_{3}$ Films
}

(Kesan Kadar Aliran Hidrogen Sepuh Lindap pada Struktur, Sifat Optik dan Elektrik Filem Fe Terdop $\mathrm{In}_{2} \mathrm{O}_{3}$ yang Disintesis Melalui Sol-Gel)

\author{
N.B. IBRAHIM*, N.F. ZULKIFLI, L.N. LAU, A.Z. ARSAD \& N. YUSOP
}

\begin{abstract}
Diluted magnetic semiconductors (DMSS) have always been of great interest to study due to their wide applications in spintronics. This research was carried out to study the influence of different hydrogen gas flow rates annealing on the physical properties of $\mathrm{Fe}$ doped indium oxide. In ${ }_{192} \mathrm{Fe}_{0.08} \mathrm{O}_{3}$ thin films were prepared by a sol-gel method and followed by a spin coating technique. Different flow rates of hydrogen gas were applied during the annealing process. All samples showed high orientation along the (222) direction and exhibit a polycrystalline structure. Grain size increased as the flow rate increased due to the stronger reduction of $H_{2}$. FTIR studies showed the existence of an $O$ - $H$ bond in the range of $3000-4000 \mathrm{~cm}^{-1}$ and it was caused by the flow of $\mathrm{H}_{2}$ gas during the annealing process. The resistivity of In ${ }_{1.92} \mathrm{Fe}_{0.08} \mathrm{O}_{3}$ thin films decreased and the carrier concentration increased with increasing hydrogen flow rates. This work has significance on the size-dependent properties and the chemical bonding in Fe doped $\operatorname{In}_{2} \mathrm{O}_{3}$ films.
\end{abstract}

Keywords: FTIR; $\mathrm{H}_{2}$ gas flow rate; iron doped indium oxide; thin film

\section{ABSTRAK}

Semikonduktor magnetik cair (DMSS) sentiasa menjadi tarikan utama untuk dikaji disebabkan penggunaannya yang meluas dalam spintronik. Kajian ini dijalankan untuk mengkaji kesan perbezaan aliran gas hidrogen sepuh lindap pada sifat fizikal filem Fe terdop indium oksida. Filem $\mathrm{In}_{1.92} \mathrm{Fe}_{0.08} \mathrm{O}_{3}$ telah disediakan melalui kaedah sol-gel diikuti dengan teknik salutan putaran. Kadar aliran gas hidrogen yang berlainan digunakan semasa proses penyepuh lindapan. Kesemua sampel menunjukkan orientasi tinggi pada arah (222) dan berstruktur polihablur. Saiz butiran bertambah apabila kadar aliran bertambah disebabkan pengurangan $\mathrm{H}_{2}$. Kajian FTIR menunjukkan kewujudan ikatan O-H dalam julat 3000 $4000 \mathrm{~cm}^{-1}$ dan ia disebabkan oleh aliran gas $\mathrm{H}_{2}$ semasa proses penyepuh lindapan. Kerintangan filem nipis In ${ }_{1.92} \mathrm{Fe}_{0.08} \mathrm{O}_{3}$ menurun dan kepekatan pembawa meningkat dengan peningkatan kadar aliran Kajian ini mempunyai keberertian pada sifat kebergantungan kepada saiz dan ikatan kimia dalam filem Fe terdop $\mathrm{In}_{2} \mathrm{O}_{3}$.

Kata kunci: Fe terdop indium oksida; filem nipis; FTIR; kadar aliran gas $\mathrm{H}_{2}$

\section{INTRODUCTION}

Indium oxide $\left(\mathrm{In}_{2} \mathrm{O}_{3}\right)$ is a promising transparent semiconductor oxides (TCO) attributes to its excellent electrical conductivity and optical transparency behaviour. It can be applied into many useful applications such as solar cells, gas sensors and flat panel displays (Beena et al. 2010; Korotcenkov et al. 2004; Phanichphant 2014). $\mathrm{In}_{2} \mathrm{O}_{3}$ belongs to an n-type semiconductor whereby oxygen vacancies can induce the formation of new energy levels in the band gap (Cao et al. 2003). Doping of magnetic metallic elements into non-magnetic conventional semiconductors have been attracted wide interest from researches since the theoretical prediction by Dietl et al. (2000) that room temperature ferromagnetism could be obtained from Mn doped semiconductors. Intense researches had been dedicated to the study of diluted magnetic semiconductors (DMSs) since then due to their potential applications in spintronics field (Wolf et al. 2001).
Recently, Ibrahim et al. (2013) have reported on $\mathrm{In}_{2-}$ ${ }_{x} \mathrm{Fe}_{x} \mathrm{O}_{3}$ thin films with $x=0.0,0.05,0.25,0.35$ and 0.45 prepared by a sol-gel method followed by a spin coating technique. The films were annealed in air atmosphere. It has been reported that doping $\mathrm{Fe}$ in $\mathrm{In}_{2} \mathrm{O}_{3}$ films resulted in the high solubility of Fe, which was $\sim 0.45$, have smooth surfaces (0.96-2.0 nm), high transmission (over $91 \%$ ) and large energy band gaps of (3.72-3.78) eV thus making it potentially useful as electrodes in solar cells or in photovoltaic and flat panel display applications.

The parameter of annealing process will highly influence the physical properties of thin films. Wang et al. (2014) have reported that $\mathrm{H}_{2}$ flow rates during the annealing process can affect the oxygen vacancies and generate more defects and also charge carrier in aluminium-doped zinc oxide (AZO) thin films. Huang et al. (2012) reported that the surface morphology of $\mathrm{ZnO}$ films had been improved significantly by annealing the film in hydrogen atmosphere due to the role of hydrogen in influencing the surface 
diffusion and sticking processes of the films. Therefore, in this study, the effect of different $\mathrm{H}_{2}$ gas flow rates during annealing process on the microstructure, chemical bonding, electrical properties and optical properties of $\mathrm{In}_{1.92} \mathrm{Fe}_{0.08} \mathrm{O}_{3}$ thin films will be our main concerned. According to our research (Zulkifli 2015), the morphology of Fe doped indium oxide $\left(\operatorname{In}_{2-x} \mathrm{Fe}_{x} \mathrm{O}_{3}, \mathrm{x}=0.00,0.025,0.05,0.08\right.$ and $0.15)$ prepared using the sol-gel method and annealed in hydrogen atmosphere, changes due to the changes of Fe. The microstructures were composed of grains of varying sizes and shapes (consist of circles and rod grains) (Zulkifli 2015). Among these films, the best morphology of a film is one with $x=0.08$ due to the uniform distribution of the grain shapes. However, the morphology of $\mathrm{In}_{1.92} \mathrm{Fe}_{0.08} \mathrm{O}_{3}$ films need further improvements, therefore, the properties of the films are also enhanced thus enabling its usage for a wide variety of applications.

\section{EXPERIMENTAL DETAILS}

$\mathrm{In}_{1.92} \mathrm{Fe}_{0.08} \mathrm{O}_{3}$ thin films were prepared by a sol-gel method followed by a spin coating technique. Iron (III) chloride hexahydrate $\left(\mathrm{FeCl}_{3} 6 \mathrm{H}_{2} \mathrm{O}, 99 \%\right.$ purity, Sigma Aldrich) and indium (III) nitrate hydrate ( $\mathrm{In}\left(\mathrm{NO}_{3}\right) . \mathrm{H}_{2} \mathrm{O}, 99.99 \%$ purity, Sigma Aldrich) were used as the starting material while absolute ethanol (J.T. Barker) and acetylacetone (99\% purity, Sigma Aldrich) were used as solvents. The preparation of $\mathrm{In}_{1.92} \mathrm{Fe}_{0.08} \mathrm{O}_{3}$ films with the Fe content of $\times$ $=0.08$ consisted of mixing the indium (III) nitrate hydrate and iron (III) chloride hexahydrate. The chemical reaction for the film with $x=0.08$ could be represented using the chemical equations shown in (1) and (2):

$$
\begin{aligned}
& (2-\times)\left(\ln \left(\mathrm{NO}_{3}\right) \cdot \mathrm{H}_{2} \mathrm{O}\right)+(\times)\left(\mathrm{FeCl}_{3} \cdot 6 \mathrm{H}_{2} \mathrm{O}\right) \rightarrow \\
& \ln _{2-\mathrm{x}} \mathrm{Fe}_{\mathrm{x}} \mathrm{O}_{3}+\text { complex ions }
\end{aligned}
$$

$$
\begin{aligned}
& (1.92)\left(\ln \left(\mathrm{NO}_{3}\right) . \mathrm{H}_{2} \mathrm{O}\right)+(0.08)\left(\mathrm{FeCl}_{3} \cdot 6 \mathrm{H}_{2} \mathrm{O}\right) \rightarrow \\
& \ln _{2-\mathrm{x}} \mathrm{Fe}_{\mathrm{x}} \mathrm{O}_{3}
\end{aligned}
$$

The molecular weight of $\ln \left(\mathrm{NO}_{3}\right) . \mathrm{H}_{2} \mathrm{O}$ is $318.8479 \mathrm{~g} /$ mol and for $\mathrm{FeCl}_{3}$. $6 \mathrm{H}_{2} \mathrm{O}$ is $270 \mathrm{~g} / \mathrm{mol}$. For $\times=0.08$, the total molecular weight of $\ln _{2-\mathrm{x}} \mathrm{Fe}_{\mathrm{x}} \mathrm{O}_{3}$ solution was $272.9224 \mathrm{~g} / \mathrm{mol}$.

Hence, the formula used to calculate the weight of starting material $\left(\ln \left(\mathrm{NO}_{3}\right) \cdot \mathrm{H}_{2} \mathrm{O}\right)$ was:

Mass $=$ mol $\times$ molecular weight of $\left(\ln \left(\mathrm{NO}_{3}\right) \cdot \mathrm{H}_{2} \mathrm{O}\right)$

For $\left(\mathrm{FeCI}_{3} \cdot 6 \mathrm{H}_{2} \mathrm{O}\right)$, the weight of starting material was:

$$
\text { Mass }=\mathrm{mol} \times \text { molecular weight of }\left(\mathrm{FeCl}_{3} \cdot 6 \mathrm{H}_{2} \mathrm{O}\right)
$$

Indium (III) nitrate hydrate $(1.1215 \mathrm{~g})$ was first dissolved in ethanol and acetylacetone while iron (III) chloride hexahydrate $(0.0396 \mathrm{~g})$ was dissolved in ethanol. Each solution was stirred for $1 \mathrm{~h}$ at room temperature $\left(25^{\circ} \mathrm{C}\right)$ using a magnetic stirrer. The solutions were then mixed and stirred again for $2 \mathrm{~h}$. Then it was filtered using a $0.45 \mu \mathrm{m}$ syringe filter and aged for 48 h. $0.2 \mathrm{~mL}$ of the solution was dropped onto a clean glass substrate and spin coated at 1500 r.p.m. for 30 s. The coated layer was dried at $70^{\circ} \mathrm{C}$ in an oven for $20 \mathrm{~min}$ to evaporate the organic solvent. All samples were placed inside a furnace tube (HTF90-13/150 model), then annealed in a hydrogen atmosphere $\left(99.99 \%\right.$ purity) at $500^{\circ} \mathrm{C}$ for 30 min in different hydrogen flow rates $(10,20,30,40$, and $50 \mathrm{sccm})$ with heating and cooling rates of $5^{\circ} \mathrm{C} / \mathrm{min}$. The period of the hydrogen gas flow at $500^{\circ} \mathrm{C}$ was about $30 \mathrm{~min}$. The hydrogen gas flow is controlled by Kofloc RK 1200 Hydrogen Gas Flowmeter. For safety reason, the outgoing hydrogen gas was flowed into a beaker of water during the annealing process. The phase and crystal structure of films were investigated using an X-ray diffractometer (Bruker Discover $8 \mathrm{XRD}$ ) with $\mathrm{Cu}-\mathrm{K} \alpha$ radiation $(\lambda=0.15406 \mathrm{~nm})$. The data of all the films were analyzed using a Bruker EVA software (version 2). The film surface morphology was studied using a field emission scanning electron microscope (Zeiss Merlin Compact operated at $3 \mathrm{KV}$ ). A Hall Effect Measurement System (HEMS) that consists of Keithley 2700 multimeter and Keithley 2400 sourcemeter was used to study the electrical properties of the films. The FTIR absorption characteristics of films were measured using a Fourier Transform Infrared Spectroscopy (Perkin Elmer Spectrum BX FT-IR) in the range of $400-4000 \mathrm{~cm}^{-1}$.

\section{RESULTS AND DISCUSSION}

Figure 1 shows the XRD patterns of $\operatorname{In}_{1.92} \mathrm{Fe}_{0.08} \mathrm{O}_{3}$ thin films prepared at different flow rates of hydrogen gas during the annealing process. All samples show good match with pure $\mathrm{In}_{2} \mathrm{O}_{3}$ (JCPDS 006-0416) with strong orientation along the (222) direction and exhibit polycrystalline structure. There is no peak corresponding to the $\mathrm{Fe}$ indicating that $\mathrm{Fe}$ ions have merged into $\mathrm{In}_{2} \mathrm{O}_{3}$ structure during the annealing process (Ibrahim et al. 2013; Yoo et al. 2005). Figure 2 indicates that (222) peak shift which is attributes to the replacement of $\operatorname{In}^{3+}$ (ionic radius $=0.80 \AA$ ) by a smaller radius of $\mathrm{Fe}^{3+}$ (ionic radius $=0.645 \AA$ ) (Shannon 1976).

The lattice parameter of films was calculated using a full pattern matching function in the EVA software. In this function, the XRD pattern was fitted with the standard data (JCPDS card number 006-0416) using empirical models for a peak shape. The relative reliability $\left(R / R_{0}\right)$ values in Table 1 represents the credibility of lattice parameters estimated from the EVA software. The value that is closer to 1 will be the most accurate value. The crystalline size was calculated using a Scherrer's equation which the calculation was done at the (222) peak. The value of $\mathrm{K}$ factor used in the calculation is 0.89 . The results are summarized in Table 1. The film's thickness and surface morphology were analysed by a field emission scanning electron microscope (FESEM). Figures 3 and 4 show the morphology and cross section FESEM images of $\mathrm{In}_{1.92} \mathrm{Fe}_{0.08} \mathrm{O}_{3}$ thin films, respectively. The measured grain 


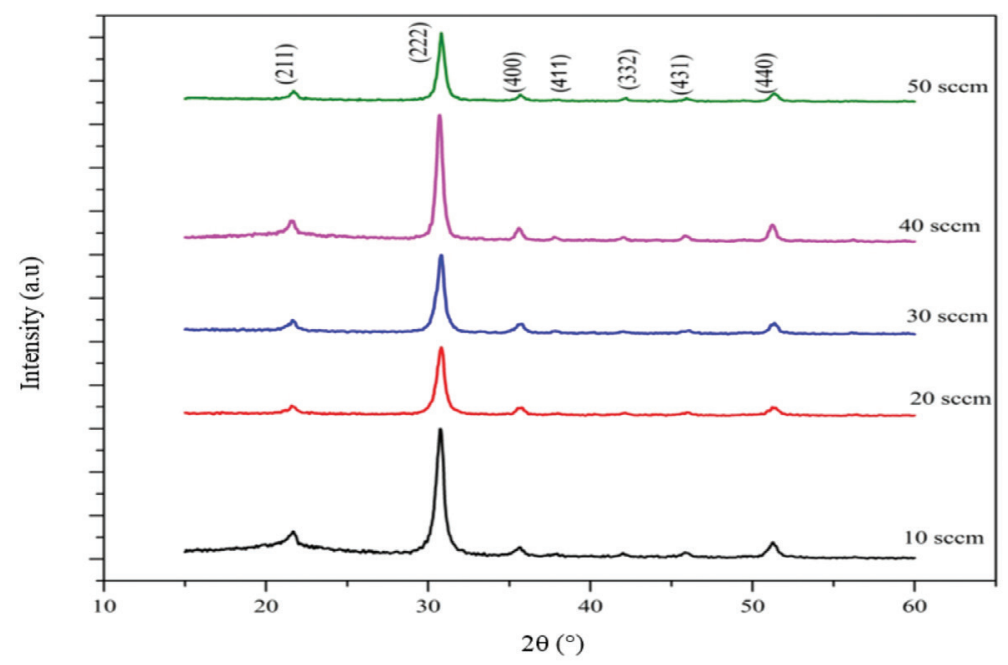

FIGURE 1. XRD patterns of $\mathrm{In}_{1.92} \mathrm{Fe}_{0.08} \mathrm{O}_{3}$ with different $\mathrm{H}_{2}$ flow rate $(10,20,30$, 40 , and $50 \mathrm{sccm}$ ) during the annealing process

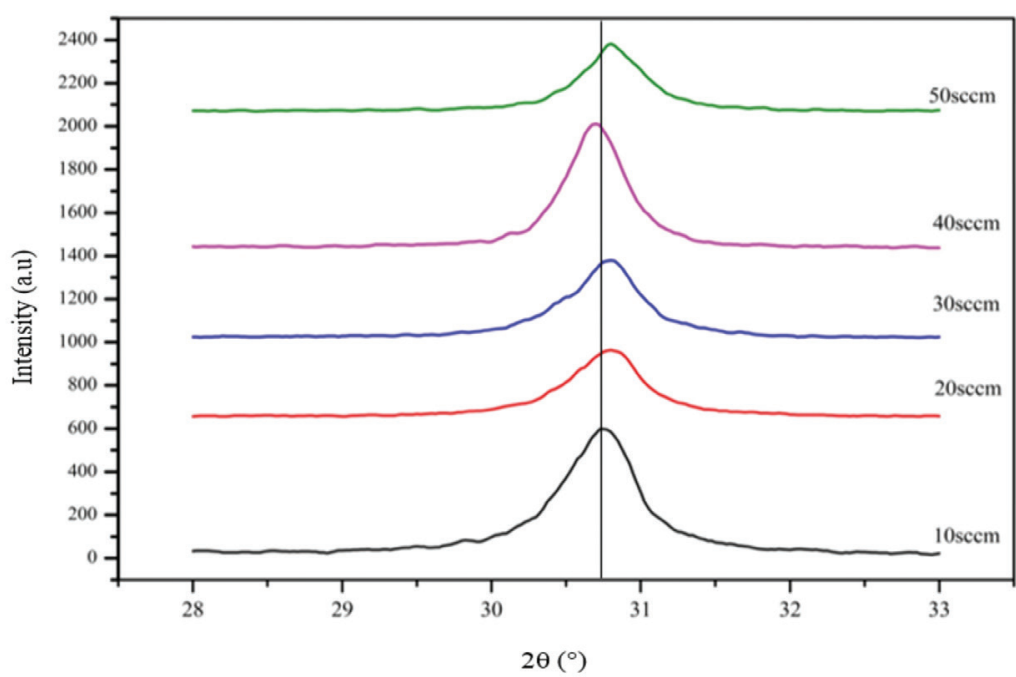

FIGURE 2. XRD pattern at peak (222) of $\mathrm{In}_{1.92} \mathrm{Fe}_{0.08} \mathrm{O}_{3}$ thin films with different $\mathrm{H}_{2}$ flow rate $(10$ to $50 \mathrm{sccm})$ during annealing process

TABLE 1. The lattice parameter, relative reliability, crystal size, grain size and thickness of $\mathrm{In}_{1.92} \mathrm{Fe}_{0.08} \mathrm{O}_{3}$ thin films annealed at different $\mathrm{H}_{2}$ flow

\begin{tabular}{ccccc}
\hline $\begin{array}{c}\text { Hydrogen } \\
\text { gas flow } \\
\text { rate }(\mathrm{sccm})\end{array}$ & $\begin{array}{c}\text { Lattice parameter } \mathrm{a}=\mathrm{b}=\mathrm{c}(\AA) \\
\text { at peak }(222) \\
( \pm 0.0001)\end{array}$ & $\begin{array}{c}\text { Relative reliability } \\
\mathrm{R} / \mathrm{R}_{0}\end{array}$ & $\begin{array}{c}\text { Crystal size at peak } \\
(222) \\
( \pm 0.01 \mathrm{~nm})\end{array}$ & $\begin{array}{c}\text { Thickness } \\
( \pm 0.01 \mathrm{~nm})\end{array}$ \\
\hline 10 & 10.1070 & 0.726 & 15.01 & 122.80 \\
20 & 10.0927 & 0.836 & 15.06 & 98.02 \\
30 & 10.0766 & 0.655 & 15.74 & 89.32 \\
40 & 10.1023 & 0.731 & 17.85 & 87.09 \\
50 & 10.1025 & 0.946 & 16.59 & 87.09 \\
\hline
\end{tabular}

size, thickness and crystallite size were plotted against the hydrogen gas flow rate as shown in Figure 5. The grain size increases with the increment of the gas flow rate. This shows that the increasing gas flow rate eliminates the free surface energy of grains, inducing the formation of grain boundary thus coalescing the grain to form bigger grains. This phenomenon can be compared to the results reported by $\mathrm{Zhu}$ et al. (2011) for $\mathrm{ZnO}$ films annealed in 

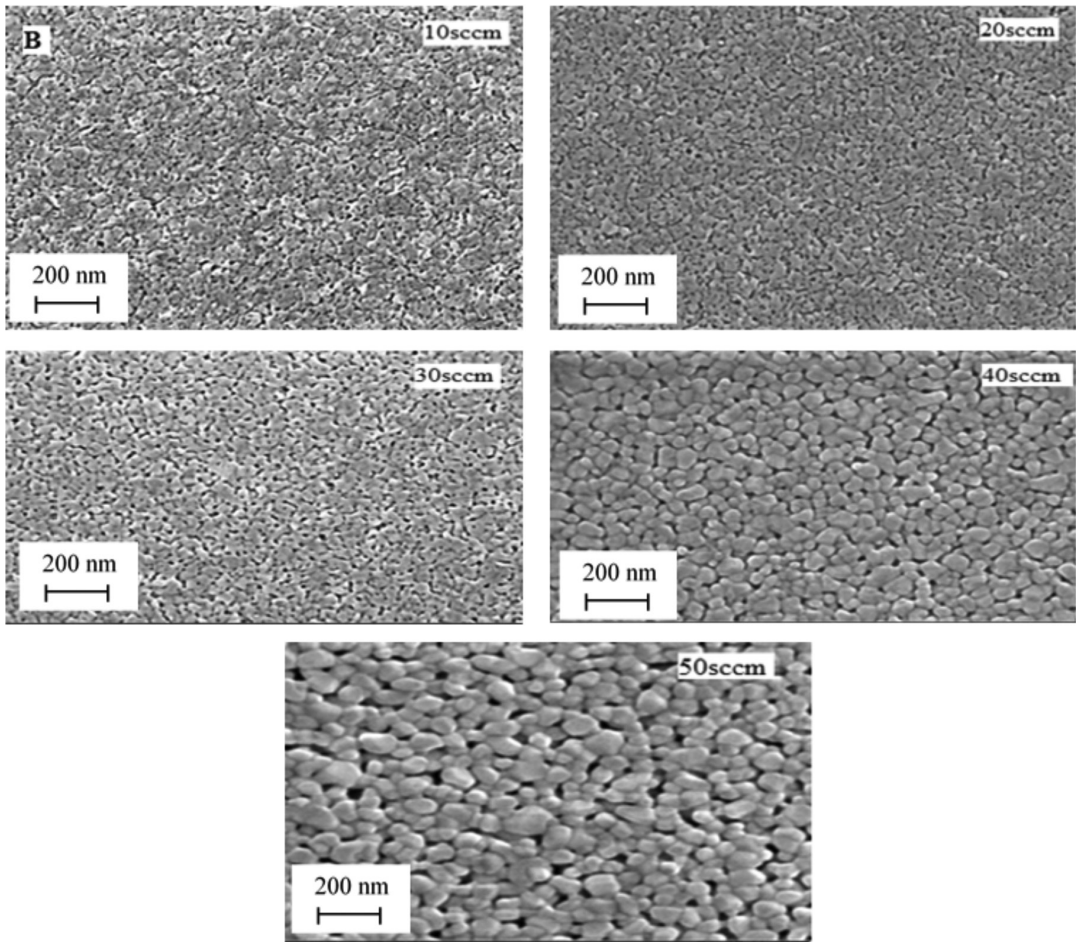

FIGURE 3. Morphology of $\operatorname{In}_{1.92} \mathrm{Fe}_{0.08} \mathrm{O}_{3}$ thin films with different (10 to $50 \mathrm{sccm}$ ) during annealing process
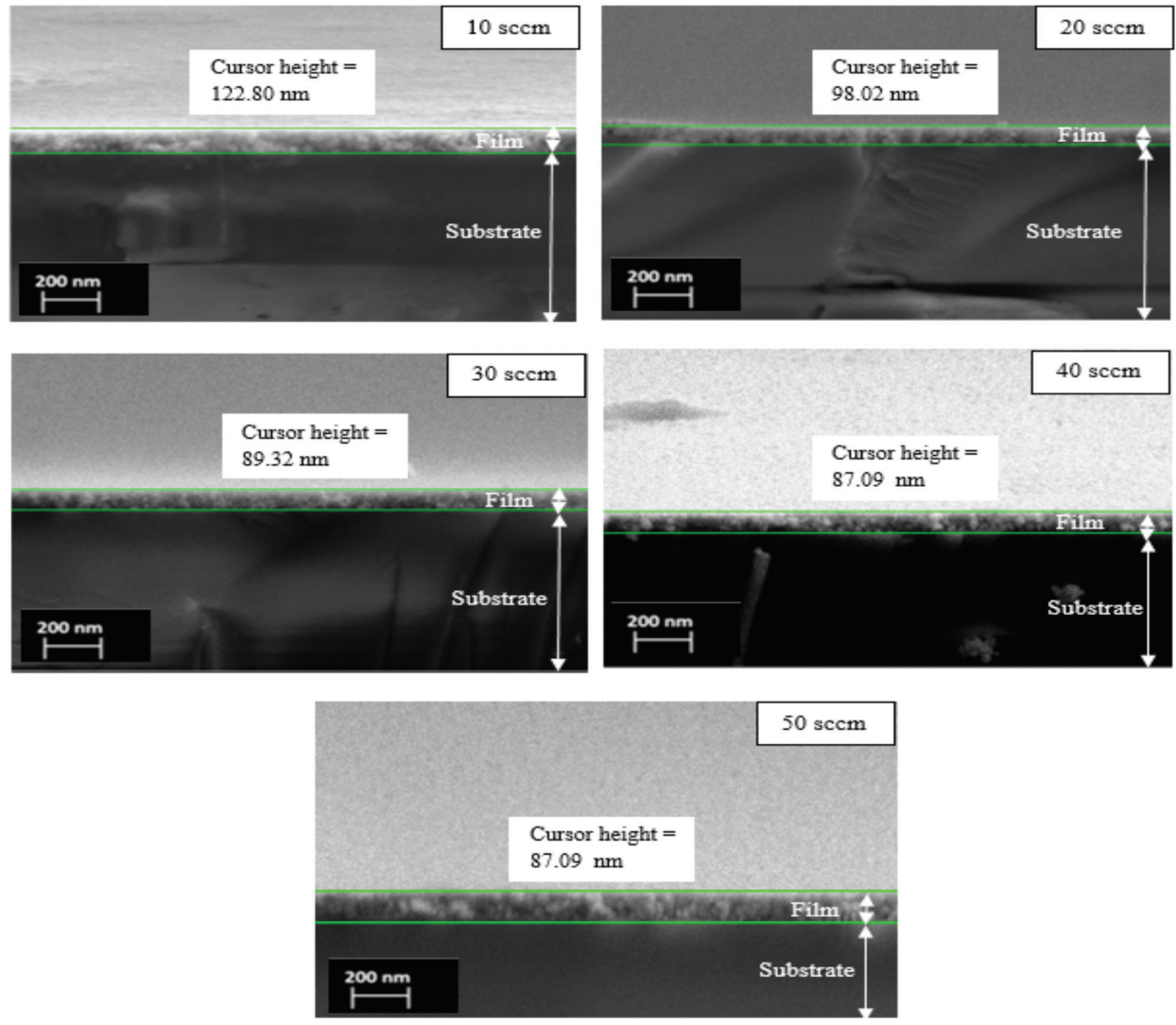

FIGURE 4. The cross section FESEM images for $\operatorname{In}_{1.92} \mathrm{Fe}_{0.08} \mathrm{O}_{3}$ thin films with different (10 to $50 \mathrm{sccm}$ ) during annealing process 
the hydrogen atmosphere. They reported an increment of grain size due to the increment of $\mathrm{H}_{2}$ On the other hand, the film's thickness decreases with the increment of grain size (Figure 5). Theoretically, when the grain size increases, it causes an increase in the film's thickness, but the decrease of the thickness occurs due to the densification process in the film.

Chemical bonds within a material can be determined using an FTIR spectroscopy. The frequency range between $400-4000 \mathrm{~cm}^{-1}$ and $4 \mathrm{~cm}^{-1}$ resolution was used to investigate the samples. Figure 6 shows the three regions of the FTIR spectrum of the films. Incorporation of hydrogen produces a weak band located at peaks between 2300 and $2222 \mathrm{~cm}^{-1}$ (Region A) and 3700 and $3500 \mathrm{~cm}^{-1}$ (Region B). However, there is no significant increase in the intensity as the hydrogen gas flow rate increases. Figure 7 shows the peaks at wavenumber $542,537.28$, and 543.40 $\mathrm{cm}^{-1}$ which are related to the $\mathrm{Fe}_{2} \mathrm{O}_{3}$ (Majeed et al. 2013; Saikia \& Parthasarathy 2010) while the wave number at $451.61,553.76,482.80$, and $449.10 \mathrm{~cm}^{-1}$ are related to metal oxide bond and In-O bond (Majeed et al. 2013).

Figure 8 shows the FTIR spectrum at Region A fitted to the Gaussian peak function using the OriginPro software. Two peaks of O-H bond exist in the range $3000-4000$ $\mathrm{cm}^{-1}$ and it was caused by the flow of $\mathrm{H}_{2}$ gas during the annealing process. When $\mathrm{H}_{2}$ is introduced into the furnace during the annealing process, some of the gas reacts with the oxygen at the film's surface, thus producing water molecules. Some of the water molecules in turn will form $\mathrm{O}-\mathrm{H}$ bonds in the sample and finally induce neutral oxygen vacancies $\left(\mathrm{V}_{\mathrm{O}}\right)$ and free carriers. The Vo could be singly ionized vacancies and doubly ionized vacancies (Kroger Vink notation). This reaction may take place according to the equations (6), (7), (8) and (9).

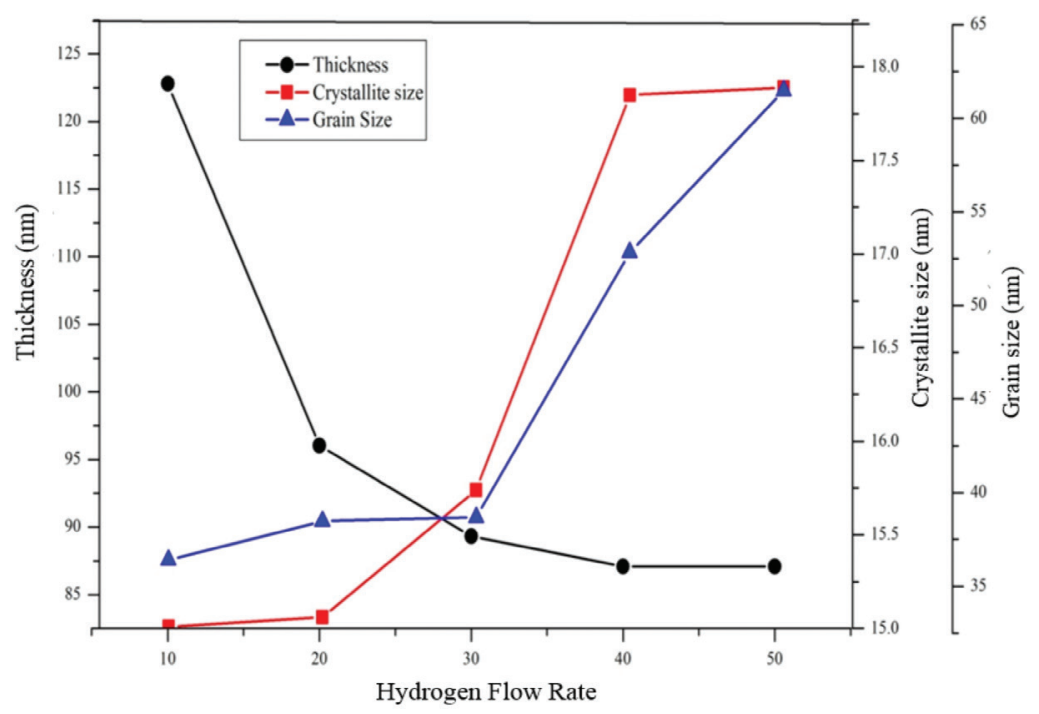

FIGURE 5. Graph of thickness, grain size and crystal size $\operatorname{In}_{1.92} \mathrm{Fe}_{0.08} \mathrm{O}_{3}$ thin films with different (10 to $50 \mathrm{sccm}$ ) during annealing process

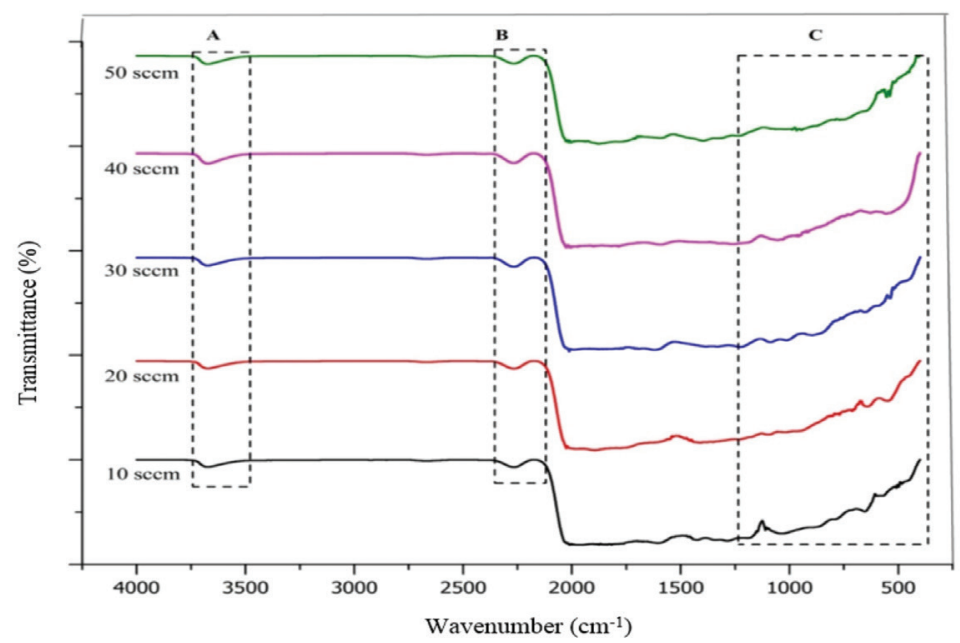

FIGURE 6. The three region of the FTIR spectrum of $\operatorname{In}_{1.92} \mathrm{Fe}_{0.08} \mathrm{O}_{3}$ thin films with different (10 to $50 \mathrm{sccm}$ ) during annealing process 


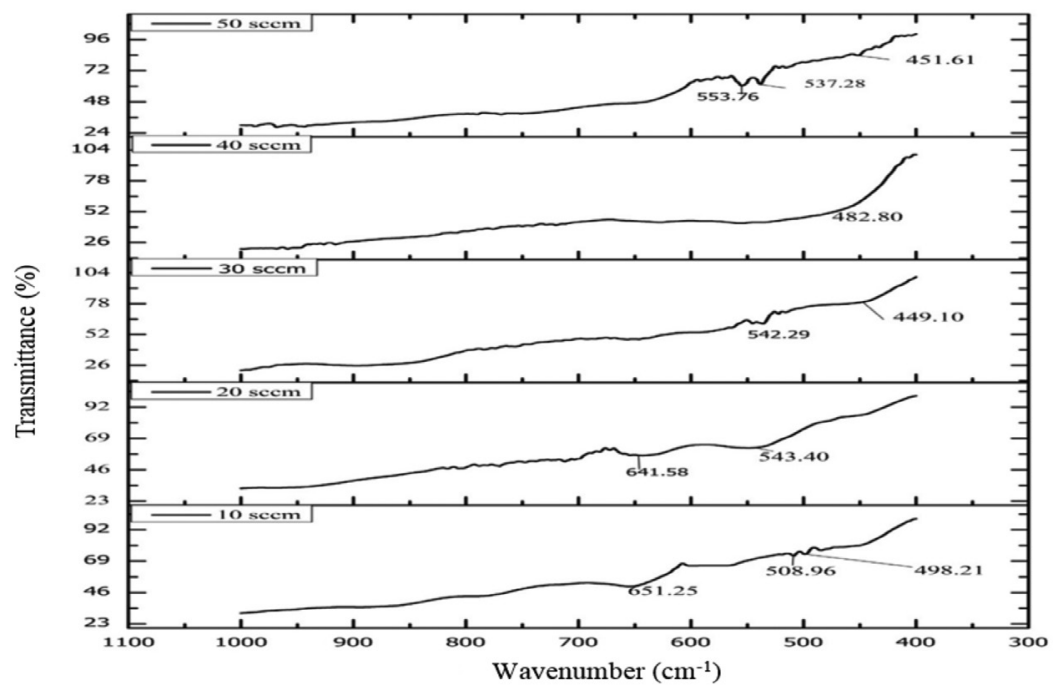

FIGURE 7. FTIR spectrum (Region C) of $\mathrm{In}_{1.92} \mathrm{Fe}_{0.08} \mathrm{O}_{3}$ thin films with different $(10$ to $50 \mathrm{sccm})$ during annealing process

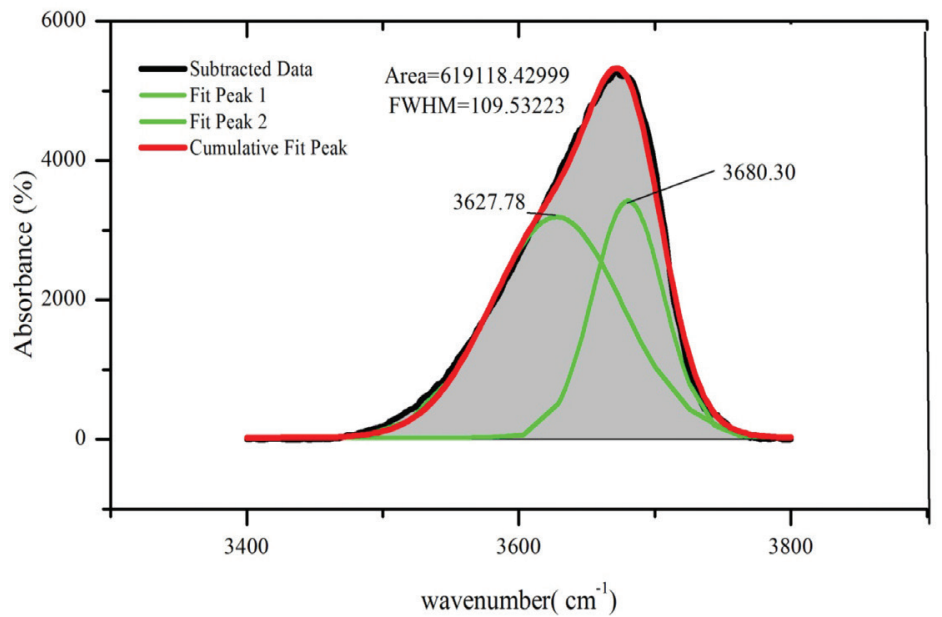

FIGURE 8. The deconvoluted FTIR spectrum of $\operatorname{In}_{1.92} \mathrm{Fe}_{0.08} \mathrm{O}_{3}$ thin film for 10 sccm of hydrogen gas during annealing process

$$
\begin{aligned}
& \mathrm{H}_{2+} \mathrm{O}^{2-} \rightarrow \mathrm{H}_{2} \mathrm{O}+2 \mathrm{e}^{-} \\
& 2 \mathrm{O}^{2-}+\mathrm{H}_{2} \rightarrow 2 \mathrm{OH}^{-}+2 \mathrm{e} \\
& \mathrm{V} 0 \leftrightarrow \mathrm{V}_{0}^{\bullet}+\mathrm{e}^{-} \\
& \mathrm{V}_{0}^{\bullet} \rightarrow \mathrm{V}_{0}^{\bullet \bullet}+\mathrm{e}^{-}
\end{aligned}
$$

Based on the FTIR spectrum, an area under the graph can be used to represent the number of components in the materials. The calculation of the area under the graph of the $\mathrm{O}-\mathrm{H}$ bond region was tabulated in Table 2. The peak positions of peak 1 and peak 2 were shifted to a lower wavenumber at a higher flow of hydrogen gas, indicating a lessening of the bond strength of the hydroxyl.

Electrical properties of the $\mathrm{In}_{1.92} \mathrm{Fe}_{0.08} \mathrm{O}_{3}$ thin films were analysed by a Hall Effect Measurement System and the connections were done by the Van der Pauw method. The measurements were carried out in room temperature $\left(29^{\circ} \mathrm{C}\right)$ and a dark atmosphere to prevent the photoconductive effect as it will affect the accuracy of measurements (Flores-Mendoza et al. 2008; Lau et al. 2015). Figure 9 shows that the resistivity of $\operatorname{In}_{1.92} \mathrm{Fe}_{0.08} \mathrm{O}_{3}$ thin films decreases and the carrier concentration increases with increasing hydrogen flow rates. A reducing gas such as $\mathrm{H}_{2}$ can be chemisorbed on the surface of an n-type semiconductor and react with the oxygen on the surface of the films. Thus, it will result in extra electrons on the material surface, hence reducing the resistivity of n-type semiconductor (Arafat et al. 2012; Ayeshamariam et al. 2013) (6 - 9).

The amount of hydroxyl groups $(\mathrm{O}-\mathrm{H})$ formed in the films is estimated from the area under the graph as shown in Figure 8. The results tabulated in Table 2 show that a hydroxyl group $(\mathrm{O}-\mathrm{H})$ exists in all of the films. Comparing the resistivity in Figure 9 with the amount of $(\mathrm{O}-\mathrm{H})$ in the 
TABLE 2. The deconvoluted parameter of Gauss Amp and Integrated Gadget of $\mathrm{In}_{1.92} \mathrm{Fe}_{0.08} \mathrm{O}_{3}$ thin films with different hydrogen gas flowrates

\begin{tabular}{cccc}
\hline $\begin{array}{c}\text { Rate of } \mathrm{H}_{2} \text { flow } \\
(\mathrm{sccm})\end{array}$ & $\begin{array}{c}\text { Peak 1 } \\
\text { Center }\left(\mathrm{cm}^{-1}\right)\end{array}$ & $\begin{array}{c}\text { Peak 2 } \\
\text { Center }\left(\mathrm{cm}^{-1}\right)\end{array}$ & $\begin{array}{c}\text { Area under graph using } \\
\text { Integrated Gadget }\end{array}$ \\
\hline 10 & 3627.78 & 3680.30 & 619118 \\
20 & 3626.20 & 3679.63 & 852013 \\
30 & 3622.10 & 3679.71 & 1000660 \\
40 & 3624.46 & 3679.52 & 1331050 \\
50 & 3614.25 & 3677.92 & 1068420 \\
\hline
\end{tabular}

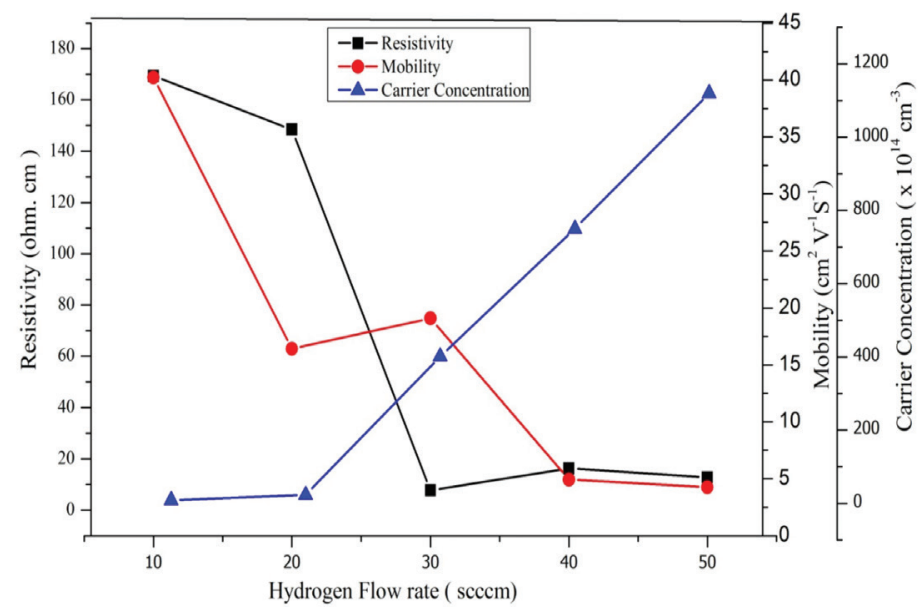

FIGURE 9. Resistivity, carrier concentration and mobility against hydrogen gas flowrate of $\mathrm{In}_{1.92} \mathrm{Fe}_{0.08} \mathrm{O}_{3}$ thin films

sample (Table 2), it shows that the changes of the resistivity are opposite to the changes in the amount of $\mathrm{O}-\mathrm{H}$ in the samples. This indicates that the increment of hydrogen gas flow rate during the annealing process can increase the conductivity of the films due to the formation of an $\mathrm{O}-\mathrm{H}$ bond. This $\mathrm{O}-\mathrm{H}$ bond creates oxygen vacancies which are other defects in the films.

The increment of hydrogen gas flow rates during the annealing process can enhance the carrier concentration in $\mathrm{In}_{1.92} \mathrm{Fe}_{0.08} \mathrm{O}_{3}$ thin film as shown in Figure 9, and a high flow rate can also influence the oxygen extraction in this film. This $\mathrm{O}-\mathrm{H}$ bond can help create oxygen vacancies in the indium oxide thin film. However, the results in Figure 9 show that the mobility and resistivity decrease as the hydrogen gas flow rate increases. Yuan et al. (2011) also reported the same trend which is unusual and summarised, that there are two factors which can give such impact to mobility, i.e. ionized impurity scattering, and grain boundary scattering. However, these mobilities of the $\mathrm{In}_{1.92} \mathrm{Fe}_{0.08} \mathrm{O}_{3}$ thin film are in the range of 5 to 40 $\mathrm{cm}^{2} \mathrm{~V}^{-1} \mathrm{~s}^{-1}$ which are higher than the one reported for $\mathrm{In}_{2} \mathrm{O}_{3}$ thin film $\left(\sim 2.57 \mathrm{~cm}^{2} \mathrm{~V}^{-1}\right)$ annealed at $500^{\circ} \mathrm{C}$ in air (Yuan et al. 2011). Ayeshamariam et al. (2013) reported that the density of ionized impurities in $\operatorname{In}_{2} \mathrm{O}_{3}$ increases when it is annealed above $400^{\circ} \mathrm{C}$. The films in this current research are annealed at $500^{\circ} \mathrm{C}$, thus this phenomenon was caused by the ionized impurity scattering.

\section{CONCLUSION}

Our focus for this work was to reveal more information about the chemical bonding in $\mathrm{Fe}$ doped $\mathrm{In}_{2} \mathrm{O}_{3}$ films throughout the FTIR analysis The hydroxyl $(\mathrm{O}-\mathrm{H})$ bond was detected from the FTIR studies and it is attributed to the flow of hydrogen gas during the annealing process. A higher flow of hydrogen gas will also decrease the strength of hydroxyl bond. There is no Fe phase detected from the XRD characterisation and this shows that it has merged into the $\mathrm{In}_{2} \mathrm{O}_{3}$ structure. The film's thickness decreases as the hydrogen gas flow rate increases, but crystallite size and grain size act oppositely. An abnormal trend was found in HEMS analysis and it was caused by the ionized impurity scattering. Different flow rates of hydrogen gas during the annealing process can affect the microstructure, chemical bonding and electrical properties of $\operatorname{In}_{1.92} \mathrm{Fe}_{0.08} \mathrm{O}_{3}$ thin films. Due to its low resistivity, high mobility and carrier concentration, the film annealed at $50 \mathrm{sccm}$ is suitable for solar cell applications.

\section{ACKNOWLEDGEMENTS}

This research was funded and supported by the Ministry of Science, Technology and Innovation, Malaysia via grant No. 03-01-02-SF0742. The authors would also like to extend their appreciation to the staff from CRIM UKM who have helped in characterisation works for this research. 


\section{REFERENCES}

Arafat, M.M., Dinan, B., Akbar, S.A. \& Haseeb, A. 2012. Gas sensors based on one dimensional nanostructured metaloxides: A review. Sensors 12: 7207-7258.

Ayeshamariam, A., Bououdina, M. \& Sanjeeviraja, C. 2013. Optical, electrical and sensing properties of $\operatorname{In}_{2} \mathrm{O}_{3}$. Materials Science in Semiconductor Processing 16: 686-695.

Beena, D., Lethy, K.J., Vinodkumar, R., Detty, A.P., Mahadevan Pillai, V.P. \& Ganesan, V. 2010. Photoluminescence in laser ablated nanostructured indium oxide thin films. Journal of Alloys and Compounds 489: 215-223.

Cao, H., Qiu, X., Liang, Y., Zhu, Q. \& Zhao, M. 2003. Roomtemperature ultraviolet-emitting $\operatorname{In}_{2} \mathrm{O}_{3}$ nanowires. Applied Physics Letters 83: 761-763.

Dietl, T., Ohno, H., Matsukura, F., Cibert, J. \& Ferrand, D. 2000. Zener model description of ferromagnetism in zinc-blende magnetic semiconductors. Science 287: 1019-1022.

Flores-Mendoza, M.A., Castanedo-Perez, R., Torres-Delgado, G., Márquez Marín, J. \& Zelaya-Angel, O. 2008. Influence of the annealing temperature on the properties of undoped indium oxide thin films obtained by the sol-gel method. Thin Solid Films 517: 681-685.

Huang, Q., Liu, Y., Yang, S., Zhao, Y. \& Zhang, X. 2012. Hydrogen mediated self-textured zinc oxide films for silicon thin film solar cells. Solar Energy Materials \& Solar Cells 103: 134-139.

Ibrahim, N.B., Baqiah, H. \& Abdullah, M. 2013. High transparency iron doped indium oxide (In2-xFe $\mathrm{xO} 3, \mathrm{x}=$ $0.0,0.05,0.25,0.35$ and 0.45$)$ films prepared by the sol-gel method. Sains Malaysiana 42(7): 961-966.

Korotcenkov, G., Brinzari, V., Golovanov, V., Cerneavschi, A., Matolin, V. \& Tadd, A. 2004. Acceptor-like behavior of reducing gases on the surface of n-type $\operatorname{In}_{2} \mathrm{O}_{3}$. Applied Surface Science 227: 122-131.

Lau, L.N., Ibrahim, N.B. \& Baqiah, H. 2015. Influence of prucursor concentration on the structural, optical and electrical properties of indium oxide thin film prepared by sol-gel method. Applied Surface Science 345: 355-359.

Majeed Khan, M.A., Khan, W., Ahamed, M., Alsalhi, M.S. \& Ahmed, T. 2013. Crystallite structural, electrical and luminescent characteristics of thin films of In2O3 nanocubes synthesized by spray pyrolysis. Electronic Materials Letters 9(1): 53-57.

Phanichphant, S. 2014. Semiconductor metal oxides as hydrogen gas sensors. Procedia Engineering 87: 795-802.
Saikia, B.J. \& Parthasarathy, G. 2010. Fourier transform infrared spectroscopic characterization of kaolinite from Assam and Meghalaya, Northeastern India. Journal of Modern Physics 1: 206-210.

Shannon, R.D. 1976. Revised effective ionic radii and systematic studies of interatomic distances in halides and chalcogenides. Acta Crystallographica 32: 751-767.

Wang, F-H., Yang, C-F., Liou, J-C. \& Chen, I-C. 2014. Effects of hydrogen on the optical and electrical characteristics of the sputter-deposited $\mathrm{Al}_{2} \mathrm{O}_{3}$-doped $\mathrm{ZnO}$ thin films. Journal of Nanomaterials 2014: 857614.

Wolf, S., Awschalom, D., Buhrman, R., Daughton, J., Von Molnar, S., Roukes, M., Chtchelkanova, A.Y. \& Treger, D. 2001. Spintronics: A spin-based electronics vision for the future. Science 294: 1488-1495

Yuan, Z., Zhu, X., Wang, X., Cai, X., Zhang, B., Qiu, D. \& Wu, H. 2011. Annealing effects of $\operatorname{In}_{2} \mathrm{O}_{3}$ thin films on electrical properties and application in thin film transistors. Thin Solid Films 519: 3254-3258.

Yoo, Y.K., Xue, Q., Lee, H-C., Cheng, S., Xiang, X-D., Dionne, G.F., Xu, S., He, J., Chu, Y.S. \& Preite, S. 2005. Bulk synthesis and high-temperature ferromagnetism of (In1xFex) 2O3- $\sigma$ with $\mathrm{Cu}$ co-doping. Applied Physics Letters 86: 042506

Zhu, B.L., Wang, J., Zhu, S.J., Wu, J., Wu, R., Zeng, D.W. \& Xie, C.S. 2011. Influence of hydrogen introduction on structure and properties of $\mathrm{ZnO}$ thin films during sputtering and postannealing. Thin Solid Films 519: 3809-3815.

Zulkifli, N.F. 2015. Kesan kadar aliran gas hidrogen ke atas mikrostruktur, ikatan kimia, sifat elektrik dan sifat optik filem $\mathrm{In}_{1.92} \mathrm{Fe}_{0.08} \mathrm{O}_{3}$ yang disediakan melalui kaedah sol-gel. Master's dissertation. Bangi: Universiti Kebangsaan Malaysia (Unpublished)

School of Applied Physics

Faculty of Science and Technology

Universiti Kebangsaan Malaysia

43600 UKM Bangi, Selangor Darul Ehsan

Malaysia

*Corresponding author; email: baayah@ukm.edu.my

Received: 19 March 2018

Accepted: 16 August 2018 